\title{
Impact of Television Media in Influencing Consumer Buying Behaviour Through Humourous Adverstisements
}

\author{
N.Senthilkumar, Anna University, India \\ S.Venkatesh, Anna University, India
}

\begin{abstract}
The evolution of information technology has resulted in the rapid development of Media in the recent times. As a result, the impact created by media on the day to day lives of individuals has also increased to a great extent. The purpose of this paper is to identify how television as an advertising media has impacted the buying behavior of consumers belonging to different demographic profiles namely age, gender, source of income and educational level respectively over a period of time through systematic review of existing literature review.This paper has also proposed a framework and set of propositions portraying the relationship between demographic variables of consumers and the impact that humor in television advertisement creates on their buying behaviors respectively.
\end{abstract}

Keywords: Humor in Advertising, Television, Consumer Memory and Ad Recall, Consumer Response to Ads 


\section{Rationale of the Study}

According to Kotler and Armstrong (2010), the term 'advertising' is coined from the Latin term "advertere", which means turning the attention towards something. Advertisement has a psychological effect on customers, and influences the customers' purchase intentions. One of the major aims of marketers is to attract the consumer's attention for establishing strong cognition paths for brand advertisements (Pieters et al. 2002). It has been pointed out by Beard (2008) that, five historical periods have been there in the development of applying humor in the advertisements. First historical period were from 1900 to 1917 when the marketers felt that humor might influence the viewers but will not support in selling the goods or product. Prior to this period, advertisers were dependent on either simple repetition of name or logo of the product or announcement advertising. Moreover, this period was when the marketers began to move towards the approach of modern advertising. The $2^{\text {nd }}$ period was from 1917 to 1940, when majority of the marketers started to understand that the humor enjoyment was a global human trait. In such period, humor emerged as the most famous element in comic strip and cartoon advertising. The $3^{\text {rd }}$ period was from 1950s and $1960 \mathrm{~s}$, which started a creative revolution (Solis et al 2014).

During this period, more amusement and entertainment were included in advertisements. In addition to this, marketers shifted more of their advertising away from radio and print, to television as well as they started to feel that advertisement must be entertaining and interesting to sell the product. Subsequent period was from 1970 to 1980, when advertisement went prior to the tough selling style of 1950s, which were influenced by economic recession. Next to that, in the 1990s, advertisers stated that, they must accept the use of humor to modify the societal factors like times, mood as well as economy in general. In addition to that, usage of humor became more famous among marketers and further, humor had changed as the most famous television advertisement strategies (Carlson2011)

Flaherty et al (2004) have stated that, advertisements play a prominent role in lives of people. Viewers obtain more information through television advertisements. Majority of the advertisers develop more techniques and approaches in the television advertising for delivering the message they like to represent. Humor is one of the famous and commonly used techniques especially in the television advertising. Television advertising adapts humor largely when compared with other strategies, since humor has been identified as the most 
influential strategy at a global level in persuading consumers to buy a product. The following figure illustrates the same:

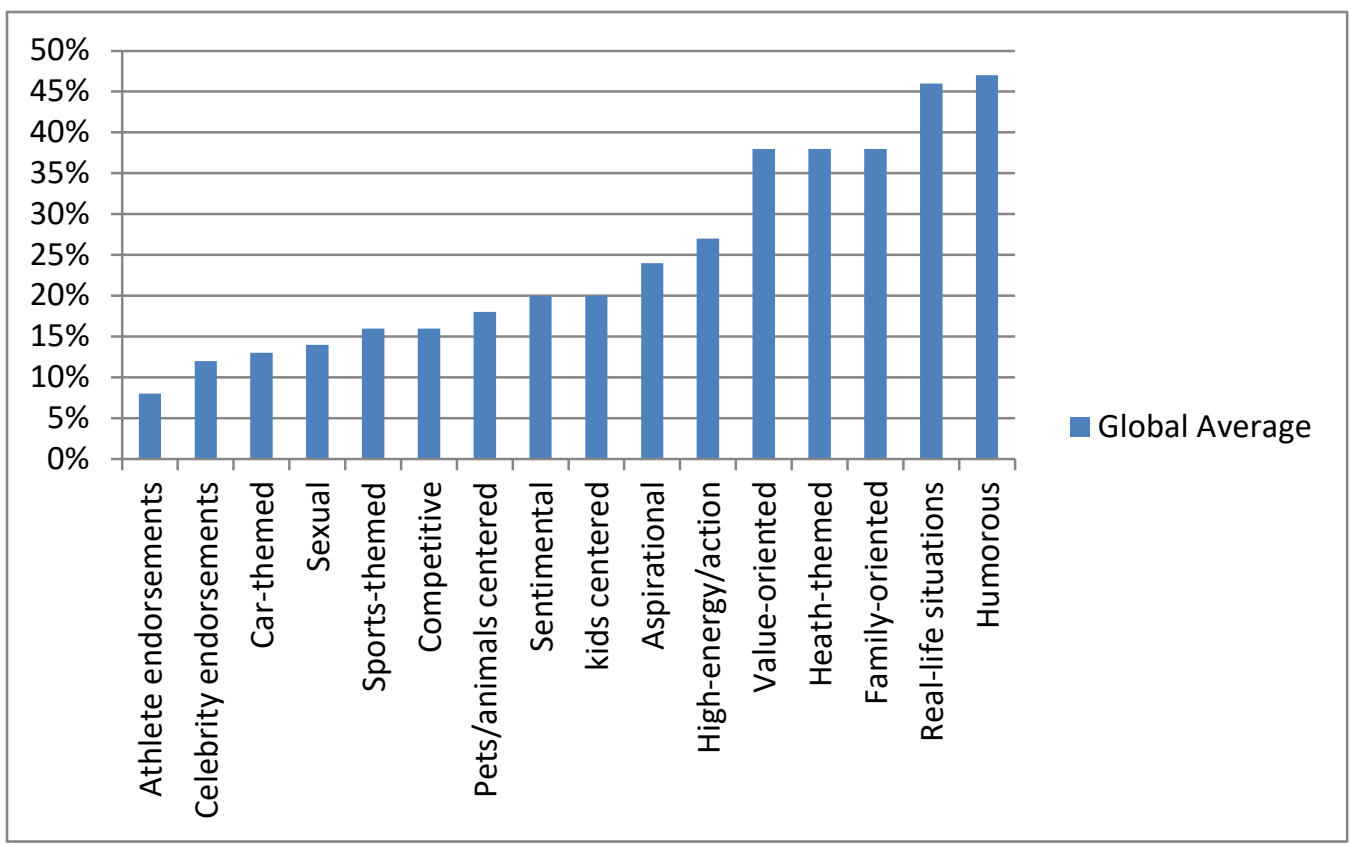

Figure 1

Consumers Preferred Types of Advertising

Nielson Global survey, 2013 as cited in Hoang, 2013

FIGURE 1 illustrates the consumers preferred types of advertising as identified by Nielson global survey, 2013. From FIGURE 1, it is evident that a majority of consumers prefer advertisements to be humorous in order to influence them to buy a product.

The aim of the research is identify how humor in television advertising impact consumers belonging to different demographic profiles namely age, gender, educational qualification and source of income through systematic review of existing literature.

\section{Literature Review}

Impact of Humorin Television Advertising on Consumers of Different Demographic Profiles

Age

Weinberger and Spotts (1989) have identified that, considering customers of all age groups, humor advertising is been identified to be superior among the young customers. Aldenet al (1993) found out that other than gender there are many other factors such as age and culture that have effect on humor effectiveness. Thus it was stated that, age factor have impact on 
humor advertisement. Olsson and Larsson (2005) examined the humor in advertisement. This study was conducted among young consumers. Young consumers opine that humor attracts attention and make people to stay or watch that advertisement in the television. It was stated by the young consumers that humor advertisements would make to remember for long term than non-humorous advertisements. It was also observed that humor would develop a positive feeling regarding the product. Thus, it can be concluded that humor advertisements influence young consumers and develop a positive feeling about the product. Shimp (2010) has discussed about the importance of humor in advertising. It is stated to be an effective and efficient method to attract the attention and focus to advertisements; it could elevate customer's recall of message points; it improves liking of both the advertised brand as well as the advertisement; it does not affect comprehension and it could maximize memory for claims of advertisement if the humor relative to brand of the advertisement and so on. Eisend (2011a) referred that humor minimizes negative cognitions regarding the advertisement since it would be a distraction from counter-argumentation.

Similarly Gurkaynak et al (2011) carried out an investigation to examine the effect of humor in advertising. It was found that humor is an effective way for creating awareness, forming emotional bonds and standing out from the crowd with the brand. Apart from these, it was also identified that it has the ability to develop buzz marketing particularly among younger consumers. Thus, it can be concluded that humor was identified as an effective marketing tool for communication, in order to attract attention among the consumers.

Next to that, Strick et al (2012) carried out an investigation based on three experiments to identify how humor breaks resistance to domination of advertisements. All three experiments were carried out among university students. The age of students was between 18 and 22 . From the outcome of experiment 1, it was indicated that resistance would result in the form of negative explicit. From the result of experiment 2, it was observed that resistance would result in implicit associations of the brand. Humor prevented such negative associations of brand formation more than non-distracting neutral and positive stimuli. In addition, from the results of third experiment it was noticed that humor stimulates implicit and explicit brand associations and consumer behavior. 
Further, Bajpai et al (2012) examined the humorous advertisements and their impact on purchase behavior with specific reference to university students. The age level was from 18 to 35 years. It was observed that three factors in advertisement, which affect the consumers, are caption, appeal and personality. It was also found out that persuasion is positively and highly associated with caption or keyword used in advertisements. Thus, it can be concluded that appeal of humorous advertisement and its effectiveness were significantly and positively correlated. It was noticed that viewers or consumers form attitudes towards products based on their knowledge, perception and beliefs about such products.

According to the study by Chang and Bandyopadhyay (2013), the impacts of American humor advertising on Taiwanese customers have been analyzed. The average age was 20.9 years. Three unique perceptual dimensions were determined in the humorous advertisement processing by Taiwanese customers such as positivity appeal, quality appeal and humor appeal. It was also found out that all three dimensions related to humorous advertisements processing were positively influenced, perceived image of brand and motivation to purchase. From the findings of the study, it was clear that, young consumers had impact on humorous advertisement.

Similarly, Hoang(2013) examined the decision process of customer and its determinants, and discusses about the usage and concept of humor in advertising for identifying its effect on purchase decision of the customer. Data were collected among adolescents. From the findings of the research, it was noted that humorous advertising has more effect on customer's recall when compared to that achieved by aligning product and campaign placement. It was also noted that humor has great effect on encouraging repurchases whereas suitable for building an image for brand and gain customer's fondness. Thus, it can be concluded that, humorous advertising could attract consumers and gain customer's fondness.

According to research by Sankaran (2013), it is discussed that, the food product commercials with respect to television relative to humor appeal. Data were collected from people of age group 20 to 40. Sarcasm and exaggeration are found to be the mostly used humor appeal in the commercials 'relative to food product. It is observed that, 72 per cent of the viewers do not enjoy sarcasm; 84 per cent of the viewers are found to opine that there is a moderate usage of exaggeration in television commercials relative to food product. It was also found 
out that celebrity endorsement, humor content, music, dialogues, visuals and characterization assist them for recalling the commercial and that humor, as an element, assists the viewers for recalling the name of the product. It was thus clear that, people of age group 20 to 40 prefer usage of exaggeration in the humor appeal than sarcasm.

Motwani and Agarwal (2013) focused on the effect of humorous advertisements on customer behavior. It was found that every age group has the similar views about the humor advertisement. Poku and Owusu (2014) examined the relationship between viewer persuasion and humorous television advertisement. It was observed that, there exists significant difference among demographic characteristics such as ethnic or age among humorous advertisements. It was also found out that product nature affects the appropriateness in the treatment of humor. Moreover, it was noticed that the humor is more appropriate for products of low involvement than products of high involvement and at the same time, it was observed that humor is more appropriate for product than services. Thus, it can be concluded that there exist main variance among demographic characteristics like age or ethnic among humor advertising. TABLE 1 illustrates the impact of humor in television advertising on consumers' of different age groups.

Impact of Humour in Television Advertising on Consumers of Different Age Groups

\begin{tabular}{|l|l|l|}
\hline $\begin{array}{l}\text { Author's } \\
\text { Name }\end{array}$ & Year & Findings \\
\hline $\begin{array}{l}\text { Seinberger and } \\
\text { Spotts }\end{array}$ & 1989 & $\begin{array}{l}\text { It was observed that humour was superior among young } \\
\text { customers. }\end{array}$ \\
\hline Alden & 1993 & $\begin{array}{l}\text { It was found out that age factor have impact of humour } \\
\text { advertisement. }\end{array}$ \\
\hline $\begin{array}{l}\text { Olsson } \\
\text { and }\end{array}$ & 2005 & $\begin{array}{l}\text { It was noticed that humour advertisements influence young } \\
\text { consumers and develop a positive feeling about the product. } \\
\text { It was also observed that humour would develop a positive } \\
\text { feeling regarding the product. }\end{array}$ \\
\hline Gurkaynak et al & 2011 & $\begin{array}{l}\text { It was pointed out that humour is an effective way for } \\
\text { creating awareness, forming emotional bonds, standing out } \\
\text { from the crowd with the brand and has ability to develop }\end{array}$ \\
\hline
\end{tabular}




\begin{tabular}{|c|c|c|}
\hline & & buzz marketing particularly among younger consumers. \\
\hline Strick et al & 2012 & $\begin{array}{l}\text { Young consumers opined that humour stimulates implicit and } \\
\text { explicit brand associations and also consumer behavior. }\end{array}$ \\
\hline $\begin{array}{l}\text { Bajpai, Kumar } \\
\text { and Gautam }\end{array}$ & 2012 & $\begin{array}{l}\text { Age group from } 18 \text { to } 25 \text { consumers form attitudes towards } \\
\text { products based on their knowledge, perception and beliefs } \\
\text { about such products. }\end{array}$ \\
\hline $\begin{array}{l}\text { Chang and } \\
\text { Bandyopadhyay }\end{array}$ & 2013 & $\begin{array}{l}\text { Positivity, quality and humour appeal dimensions in } \\
\text { humorous advertisements processing were positively } \\
\text { influenced perceived image of brand and motivation to } \\
\text { purchase among young consumers. }\end{array}$ \\
\hline Hoang & 2013 & $\begin{array}{l}\text { From the adolescents point of view, humour has great effect } \\
\text { on encouraging repurchases whereas suitable for building an } \\
\text { image for brand and gain customer's fondness. It was } \\
\text { observed that humour has great effect on encouraging } \\
\text { repurchases whereas suitable for building an image for brand } \\
\text { and gain customer's fondness. }\end{array}$ \\
\hline Sankaran & 2013 & $\begin{array}{l}\text { It was noticed that age group from } 20 \text { to } 40 \text { prefer usage of } \\
\text { exaggeration in the humour appeal than sarcasm. }\end{array}$ \\
\hline $\begin{array}{l}\text { Motwani and } \\
\text { Agarwal }\end{array}$ & 2013 & $\begin{array}{l}\text { It was observed that every age group has the similar views } \\
\text { about the humour advertisement. }\end{array}$ \\
\hline $\begin{array}{l}\text { Poku } \\
\text { Owusu }\end{array}$ & 2014 & $\begin{array}{l}\text { There exists main variance among demographic } \\
\text { characteristics like age or ethnic among humour advertising. }\end{array}$ \\
\hline
\end{tabular}

\section{Gender}

Whipple and Courtney (1981) determined that men tend to enjoy sexual and aggressive humor than women do. On the other hand, women would have greater enjoyment and appreciation in terms of non-sensicalhumor. Likewise, Lammers (1991) examined the effect of gender and self-monitoring on responses to humorous advertising. Gender and selfmonitoring interactions indicated that high self-monitoring men compared with lower counterparts would be more positive towards humorous advertisements. Conversely, when high self-monitoring women compared with lower counterparts it was found to be negative. On the other hand, Attardo and Lucy (2011)focused on examining the impact of humorous advertising. It was identified that the impact of humor does not differ upon gender. It was 
also identified from the studies of MacLeod (1991); Jacoby (1991, 1998); Krishnan, and Chakravarti (2003) that there exist no gender differences.

Turckes et al (2010) focused on gender differences with certain humor typologies. It was revealed that the humor types were funnier to particular genders. It was found out from nonparametric analysis that genders view humor in commercials uniquely. In addition to this, it was noted that there are various typologies identified funnier relying on the gender. It was found out by Eisend (2010); Knoll and Eisend (2011b) that stereotyping in advertising would be based on the occupational status of the gender. Further, Chan (2011) analyzed the impact of humor in television advertising. It was found out that humors improve persuasiveness in the message when the moderating variable NFC (need for cognition) is controlled. It was observed that repeated exposure to the same humor advertisement does not harm its persuasive impact. Moreover, it was noticed that male audiences were more persuasive in terms of humor advertisement whereas female audiences were opposite to male audiences. Thus, it was clear from the findings that, male audience perceptions were totally opposite to female audiences.

Swani et al (2013) examined the impact of violent humor on advertising success based on gender perspective. This research analyzed two studies of the responses in women and men to violence in humorous advertising. Outcomes of both studies state significant variance in the responses of women and men recommending that there would be a risk in joining humor with higher physical violence in advertisements focused towards females. The second study analyzed in the path model about the role of perceived humor and social norms perceived violations on the attitudes of women and men towards the brand and advertisement. It was found out that the poor women response to more violence with humor advertisement is closely correlated with their social norms perceived violations. On the other hand, more positive response of men to such advertisements is correlated with the humor perception in the advertisements with stronger and humor violence (Hermandez et al 2014). Thus, it was concluded that the responses of men and women differ in the physical violence humor advertisement.

Baber and Parrey (2013) conducted a research to examine the effect of humor in advertisement. From the research outcome, it was revealed that there was no significant 
differences exist between female and male opinions in terms of humor with specific reference to television advertising. In addition, it was noted that humor develops a positive feeling regarding product due to funny as well as good aspects portrayed about the product in the advertisement. Thus, it can be concluded that no differences found between the views of the female and male regarding humor in television advertisement.

Dore (2011) carried out an investigation to analyze the effect of humorous advertisements on the behavior of the customer. Exploratory research pointed out that there exist a thin variance between the view of females and males, whereas from the outcomes of chi-square it was found that, there is no difference in opinions of females and males towards the advertisements. Thus, it can be concluded that there exist slight difference between the perspectives of female and male audiences.

Eisend (2014) carried out a research to examine the outcomes of experimental and contentanalytic studies about effectiveness and occurrence of gender stereotyping non-humorous and humorous advertising. It was found out that men and women are stereotyped in advertisement relied on humor in specific, conventional males were more prevalent towards the humor advertisement. On the other hand, it was noticed that females were more prevalent towards the non-humor advertisement. It was observed that the impact of such stereotypes, humor enhances the attitudes of the consumer especially if non-traditional stereotyping is used rather than traditional one. It was thus found out that stereotyped humor advertisement influences women rather than men. Sutton-Spence and Donna (2011) carried out an investigation to analyze the relationship between persuasion of viewer and humor in television advertising. It was found that there exists major variance among demographic characteristics namely gender among humor advertisement.

Arockiaraj and Morais (2014) conducted a research to examine the customer's perspective based on the ethical dimensions of commercial TV (television) advertisement. It was found that sense of humor was one of the influencing factors in watching television advertisements. It was noticed that there exist significant difference among male and female perspectives about the humor appeal in the advertisement. TABLE 2 illustrates the impact of humor in television advertising on consumers' of different genders.

Table 2 
Impact of Humour in Television Advertising on Consumers of Different Gender

\begin{tabular}{|c|c|c|}
\hline $\begin{array}{l}\text { Author's } \\
\text { Name }\end{array}$ & Year & Findings \\
\hline $\begin{array}{l}\text { Whipple } \\
\text { and } \\
\text { Courtney }\end{array}$ & 1981 & $\begin{array}{l}\text { It was observed that men tend to enjoy sexual and aggressive } \\
\text { humour than women do, whereas on the other hand women } \\
\text { would have greater enjoyment and appreciation in terms of } \\
\text { non-sensicalhumour. }\end{array}$ \\
\hline Macleod & 1991 & $\begin{array}{l}\text { From the findings it is observed that there exist no gender } \\
\text { differences. }\end{array}$ \\
\hline Lammers & 1991 & $\begin{array}{l}\text { It was found out gender and self-monitoring interactions } \\
\text { indicated that high self-monitoring men compared with lower } \\
\text { counterparts would be more positive towards the humorous } \\
\text { advertisements. It was also found out that, on the other hand } \\
\text { when high self-monitoring women compared with lower } \\
\text { counterparts it was found to be negative. }\end{array}$ \\
\hline Jacoby & 1991,1998 & It was observed that there exist no gender differences. \\
\hline Alden & 1993 & $\begin{array}{l}\text { It was observed that impact of humour does not differ upon } \\
\text { gender. }\end{array}$ \\
\hline $\begin{array}{l}\text { Krishnan } \\
\text { and } \\
\text { Chakravarti }\end{array}$ & 2003 & $\begin{array}{l}\text { Male and female have similar views regarding the humorous } \\
\text { advertisement. }\end{array}$ \\
\hline $\begin{array}{l}\text { Turckes et } \\
\text { al }\end{array}$ & 2010 & $\begin{array}{l}\text { It was noticed that the humour types are funnier to particular } \\
\text { genders. }\end{array}$ \\
\hline $\begin{array}{l}\text { Eisend } \\
\text { Knoll and } \\
\text { Eisend }\end{array}$ & $\begin{array}{l}2010 \\
2011\end{array}$ & $\begin{array}{l}\text { It was found out that stereotyping in advertising would be } \\
\text { based on the occupational status of the gender }\end{array}$ \\
\hline Chan & 2011 & $\begin{array}{l}\text { It was found out that male audience perceptions were totally } \\
\text { opposite to female audiences. }\end{array}$ \\
\hline Swani et al & 2013 & $\begin{array}{l}\text { It was observed that responses of men and women differ in } \\
\text { the physical violence humour advertisement. }\end{array}$ \\
\hline $\begin{array}{l}\text { Baber and } \\
\text { Parrey }\end{array}$ & 2013 & $\begin{array}{l}\text { There are no differences found between the views of the } \\
\text { female and male regarding humour in television }\end{array}$ \\
\hline
\end{tabular}




\begin{tabular}{|l|l|l|}
\hline $\begin{array}{l}\text { Motwani } \\
\text { and } \\
\text { Agarwal }\end{array}$ & 2013 & $\begin{array}{l}\text { There exists slight difference between the perspectives of } \\
\text { female and male audiences. }\end{array}$ \\
\hline Eisend & 2014 & $\begin{array}{l}\text { It was found out that there exists major variance among } \\
\text { demographic characteristics namely gender among humour } \\
\text { advertisement. }\end{array}$ \\
\hline $\begin{array}{l}\text { Arockiaraj } \\
\text { and Morais }\end{array}$ & 2014 & $\begin{array}{l}\text { There exist significant differences among male and female } \\
\text { perspective about the humour appeal in the advertisement. }\end{array}$ \\
\hline
\end{tabular}

\section{Source of Income}

Hang (1998) carried out an investigation for examining the relationship between personal values and personal attitudes towards general and humor appeals in advertisement. The two countries culture namely Vietnam and Malaysia were also examined. It was observed that when considering Malaysia, lower income group people agreed with humor appeals in advertisement than higher income group and on the other hand, Vietnamese were totally opposite to this. Jin and Villegas (2007) focused on the placement effect of the product in film. The emotional responses of customers about the prior brand evaluation and humorous stimuli were also examined. It was found out that there exist significant differences between income level and impact of humorous stimuli.

Mir and Khan (2012) examined the role of humor-oriented advertising at the time of crisis economy. It was stated that humor oriented advertisement plays a vital role in influencing the viewers to an advertisement. Moreover, humorous advertisements were based on novel associations positively and effectively influence the attitudes of the customers to television advertising. At the time of crisis economies, it was found out that humorous advertising would positively attract the purchase intentions of the customers. It was also observed that during crisis time, humorous advertisements with high income significantly and positively dominate the attitude of customer to humor oriented television advertisement.

Babut (2012) carried out a research to examine the Romanian customer's attitudes towards television commercials. It was observed that customers would have favorable attitude towards humor commercials and would get positive feelings such as pride, pleasure and joy. 
It was found out that lower income group people have favorable attitude towards humor appeal in the advertisements. It was observed that humor is seen as an emotional trigger that was liked by majority of the customers.

Bajpai, Kumar and Gautam (2012) carried out an investigation to analyze the impact of humorous advertisement on purchase behaviors. It was examined that, humorous advertisement could negatively influence any income group whereas repetition and expensive product of the advertisement did not affect the attitude of purchasing. It was clear that, there exists a difference among income group of customers in viewing the humorous advertisement. Lee (2012) examined about, how the customers or viewers respond to various humorous advertising types. It was observed that there were significant variances found among the consumers of varying monthly income. It was noticed that humorous advertisements would support or promote comprehension of brand message. It was also found that humorous advertisements are superior when compared to non-humorous advertisements (Recio et al 2010). Various humorous advertisement types have unique impacts on brand recall and brand recognition.

Prempeh, Boateng and Asuamah (2013) examined the factors, which influence the effectiveness of alcohol advertisement. Few respondents have opined that usage of humor in alcohol advertisement influence to purchase or buy alcohol. Demographic variables like religion and family income levels affect attitude towards alcohol advertisement. In addition to that, it was noted that factors like peers, parents, community practices and adults do not influence customer's purchase behavior of the alcohol.

Mensah, Asuamah and Amankwah (2013) analyzed the customer's attitude towards elements in the advertisement. It was revealed that majority of the customers were attracted towards humor appeal in the advertisement. It was noticed that the status of family income has significant impact on attitude towards humor appeal in the television advertisements.

According to the research by Majid (2013), which has discussed about the culture influence in advertising, it is examined that, majority of the advertisers include humorous approach for influencing the customers to buy their products. From the research results, it was found out 
that there exists a high difference among income group in getting attracted to the humorous advertisement.

Perspective of the consumers on the ethical dimensions of commercial television advertisement was examined byApter and Mitzi (2012). From the findings of the research, it was revealed that, factors, which influenced the most in watching television advertisements, are theme, sense of humor and presentation. It was also found that there exists significant difference among family income in influencing the humorous television advertisement. TABLE 3 illustrates the impact of humor in television advertising on consumers' of various sources of income.

Table 3: Impact of Humour in Television Advertising on Consumers of Various Sources Of Income

\begin{tabular}{|c|c|c|}
\hline $\begin{array}{l}\text { Author's } \\
\text { Name }\end{array}$ & Year & Findings \\
\hline Hang & 1998 & $\begin{array}{l}\text { It was observed that when considering Malaysia, lower income } \\
\text { group people agreed with humour appeals in advertisement than } \\
\text { higher income group and on the other hand Vietnamese were totally } \\
\text { opposite to this. }\end{array}$ \\
\hline $\begin{array}{l}\text { Jin and } \\
\text { Villegas }\end{array}$ & 2007 & $\begin{array}{l}\text { It was found out that there exist a significant difference exist } \\
\text { between income level and impact of humorous stimuli. }\end{array}$ \\
\hline $\begin{array}{l}\text { Mir and } \\
\text { Khan }\end{array}$ & 2012 & $\begin{array}{l}\text { At the time of crisis economies, it was found out that humorous } \\
\text { advertising would positively attract the purchase intentions of the } \\
\text { customers. It was observed that during crisis time, humorous } \\
\text { advertisements with high income significantly and positively } \\
\text { dominate the attitude of customers to humour oriented television } \\
\text { advertisement. }\end{array}$ \\
\hline Babut & 2012 & $\begin{array}{l}\text { It was found out that lower income group people have favorable } \\
\text { attitude towards humour appeal in the advertisements. It was } \\
\text { observed that humour is seen as an emotional trigger that was liked } \\
\text { by majority of the customers. }\end{array}$ \\
\hline Bajpai, & 2012 & It was found out that humorous advertisement could negatively \\
\hline
\end{tabular}




\begin{tabular}{|c|c|c|}
\hline $\begin{array}{l}\text { Kumar and } \\
\text { Gautam }\end{array}$ & & $\begin{array}{l}\text { influence any income group whereas repetition and expensive } \\
\text { product of the advertisement did not affect the attitude of } \\
\text { purchasing. }\end{array}$ \\
\hline Lee & 2012 & $\begin{array}{l}\text { It was observed that there were significant variances found among } \\
\text { the monthly income. It was noticed that humorous advertisements } \\
\text { would support or promote comprehension of brand message. It was } \\
\text { found that humorous advertisements are superior when compared to } \\
\text { non-humorous advertisements. }\end{array}$ \\
\hline $\begin{array}{l}\text { Prempeh, } \\
\text { Boateng and } \\
\text { Asuamah }\end{array}$ & 13 & $\begin{array}{l}\text { Demographic variables like religion and family income levels affect } \\
\text { attitude towards alcohol advertisement. In addition to that, it was } \\
\text { noted that factors like peers, parents, community practices and } \\
\text { adults do not influence customer's purchase behaviour of the } \\
\text { alcohol. }\end{array}$ \\
\hline $\begin{array}{l}\text { Mensah, } \\
\text { Asuamah } \\
\text { and } \\
\text { Amankwah }\end{array}$ & 013 & $\begin{array}{l}\text { It was revealed that majority of the customers were attracted } \\
\text { towards humour appeal in the advertisement. It was noticed that the } \\
\text { status of family income has significant impact on attitude towards } \\
\text { humour appeal in the television advertisements }\end{array}$ \\
\hline Majid & 2013 & $\begin{array}{l}\text { It was found out that there exists a high difference among income } \\
\text { group in attracting the humorous advertisement. }\end{array}$ \\
\hline $\begin{array}{l}\text { Arockiaraj } \\
\text { and Morais }\end{array}$ & 2014 & $\begin{array}{l}\text { It was revealed that factors which influenced most in watching } \\
\text { television advertisements are theme, sense of humour and } \\
\text { presentation. It was found out that there exists significant difference } \\
\text { among family income in influencing the humorous television } \\
\text { advertisement. }\end{array}$ \\
\hline
\end{tabular}

\section{Educational Level}

Brooker (1981) pointed out that factors like level of education would influence perceived humor. It was verified that highly educated people or customer are more sensitive towards humorous advertisement. Madden and Weinberger (1984) identified that humorous advertisements were appropriate to educated young males. McGhee (1986) and Mak and Carpenter (2007) pointed out that humor comprehension needs cognitive abilities that would be highly relied on educational level. It was also found out that, the level of education assist to identify the variations in understanding the humor. It was clear from the above analysis 
that comprehension of the humor appeal needs cognitive abilities, which would be highly dependent on the level of education.

Hang (1998) conducted a research to analyze the relationship between personal attitudes and values towards humor appeals in advertising across two nations namely Malaysia and Vietnam. It was observed that bachelor degree holders in Vietnam were more agreeable on humor appeals in advertisement than post-graduate degree holders. On the other hand, there exists slight difference among bachelor and post-graduate degree holders in Malaysia regarding humor appeals in advertisement. Thus, it was concluded that there exist difference among level of education in influencing the humor appeals in the advertisement.

Eisend (2007) carried out Meta-analysis of humor impacts in advertising. It was noticed that humor works best for well-educated consumers especially males. It was pointed out that humor influences variables as mentioned by effective models. It indicates an effect towards memory and attention. Thus, it can be concluded that the well-educated male consumers were attracted towards humor advertisement than other counterparts. Perks (2012) identified that different educational backgrounds of the consumers have different opine about the humorous advertising. Apart from these, it was also noticed that well-educated consumers are also attracted by the humorous advertisement.

Siddiqui (2011) explored the influence of customer personality of likeness of themes namely humorous advertising. Data were gathered from postgraduate and under graduate students of different universities. It was noted that differences exist among postgraduate and under graduate students for likeness of humorous advertisements. Extraversion as a personality factor had a significance difference in the likeness theme of humorous advertisement (Scolari \& Carlos 2012). It was also noticed that extraverts would possess higher tendency for experiencing positive emotions like happiness, joy, excitement and love. Thus it was concluded that difference exist between the educational levels of the consumers.

According to the study by Lee (2012) have discussed about how consumers respond to various types of humorous advertisement. It was found out that bachelor degree holders have high impact than other groups. It was also observed that various humorous advertisement types have variance on different dimensions in terms of communication of brand. It was 
verified that effective type of humorous advertisement has greater brand recall than social and cognitive.

According to the research by Yoong (2012) who have examined about the relationship between television advertisement, which is humorous, and audience persuasion, it was observed that audience like goods and services when advertised with humor. It was also observed that education level and cultural background influence the humor advertisement among audience.

Poku and Ampadu (2014) examined the impact of advertisement on consumer loyalty in telecommunications industry with respect to Ghana. It was observed that humorous advertisement nature that influenced the customers are, expressions, comical lines, appearance and gestures of the advertisement. It was observed that based on the educational level of the consumers, the perspectives about the humorous advertisement varies. TABLE 4 illustrates the impact of humor in television advertising on consumers' of various educational levels.

Impact of Humour in Television Advertising on Consumers of Various Educational Levels

\begin{tabular}{|l|l|l|}
\hline $\begin{array}{l}\text { Author's } \\
\text { name }\end{array}$ & Year & Findings \\
\hline Brooker & 1981 & $\begin{array}{l}\text { It was verified that highly educated people or customer are more } \\
\text { sensitive towards humorous advertisement. }\end{array}$ \\
\hline $\begin{array}{l}\text { Madden } \\
\text { Weinberger }\end{array}$ & 1984 & $\begin{array}{l}\text { From the findings of the research it was observed that humorous } \\
\text { advertisements were appropriate to educated younger males. }\end{array}$ \\
\hline $\begin{array}{l}\text { McGhee } \\
\text { Hang }\end{array}$ & 1986 & $\begin{array}{l}\text { It was also found out that level of education assist to identify the } \\
\text { variations in understanding the humour. }\end{array}$ \\
$\begin{array}{l}\text { It was observed that bachelor degree holders in Vietnam were more } \\
\text { agreable on humour appeals in advertisement than postgraduate } \\
\text { degree holders. On the other hand there exists slight difference } \\
\text { among bachelor and postgraduate degree holders in Malaysia } \\
\text { regarding humour appeals in advertisement. }\end{array}$ \\
\hline
\end{tabular}




\begin{tabular}{|c|c|c|}
\hline Eisend & 2007 & $\begin{array}{l}\text { It was noticed that humour works best for well-educated consumers } \\
\text { especially males. It was pointed out that humour influences variables } \\
\text { as mentioned by affective models. }\end{array}$ \\
\hline $\begin{array}{l}\text { Jin and } \\
\text { Villegas }\end{array}$ & 2007 & $\begin{array}{l}\text { Different educational backgrounds of the consumers have different } \\
\text { opine about the humorous advertising. }\end{array}$ \\
\hline $\begin{array}{l}\text { Mak and } \\
\text { Carpenter }\end{array}$ & 2007 & $\begin{array}{l}\text { It was found out that comprehension of the humour appeal needs } \\
\text { cognitive abilities which would be highly dependent on the level of } \\
\text { education. }\end{array}$ \\
\hline Sidd & 011 & $\begin{array}{l}\text { It was noted that difference exists among post graduate and under } \\
\text { graduate students for likeness of humorous advertisements. It was } \\
\text { also noticed that extraverts would possess higher tendency for } \\
\text { experiencing positive emotions like happiness, joy, excitement and } \\
\text { love. }\end{array}$ \\
\hline Lee & 2012 & $\begin{array}{l}\text { It was also observed that various humorous advertisement types have } \\
\text { variance on different dimensions in terms of communication of } \\
\text { brand. It was verified that affective type of humorous advertisement } \\
\text { has greater brand recall than social and cognitive. }\end{array}$ \\
\hline $\begin{array}{l}\text { Poku and } \\
\text { Owusu }\end{array}$ & 2014 & $\begin{array}{l}\text { It was observed that audiences like goods and services when } \\
\text { advertised with humour. It was also observed that education level and } \\
\text { cultural background influence the humour advertisement among } \\
\text { audience. }\end{array}$ \\
\hline $\begin{array}{l}\text { Poku and } \\
\text { Ampadu }\end{array}$ & 2014 & $\begin{array}{l}\text { It was observed that based on the educational level of the consumers, } \\
\text { the perspectives about the humorous advertisement varies. }\end{array}$ \\
\hline
\end{tabular}

\section{Findings and Research Framework}

It is clear from above analysis that television media plays a significant impact on influencing the buying behaviour of consumers. Television media advertisements when designed with humor would develop a positive feeling regarding the product. With respect to age, it is found out that humor advertisements influence young consumers than adolescents. When considering gender, it is noticed that humor works best for well-educated consumers especially male. At the same time, when focusing on education level, it is found that the level of education assists to identify the variations in understanding the humor. When looking into 
the perspective of source of income, it is clear that, humorous advertisementinfluence people belonging to all the income groups.

FIGURE 1portrays on how much television advertisements influence consumers to purchase a product. Most of the consumers knows about a product only through television and go for purchase. Television advertisements hold a lion's share (39.8\%) among all the sources.

\section{Sources To Learn About Products of Interest}

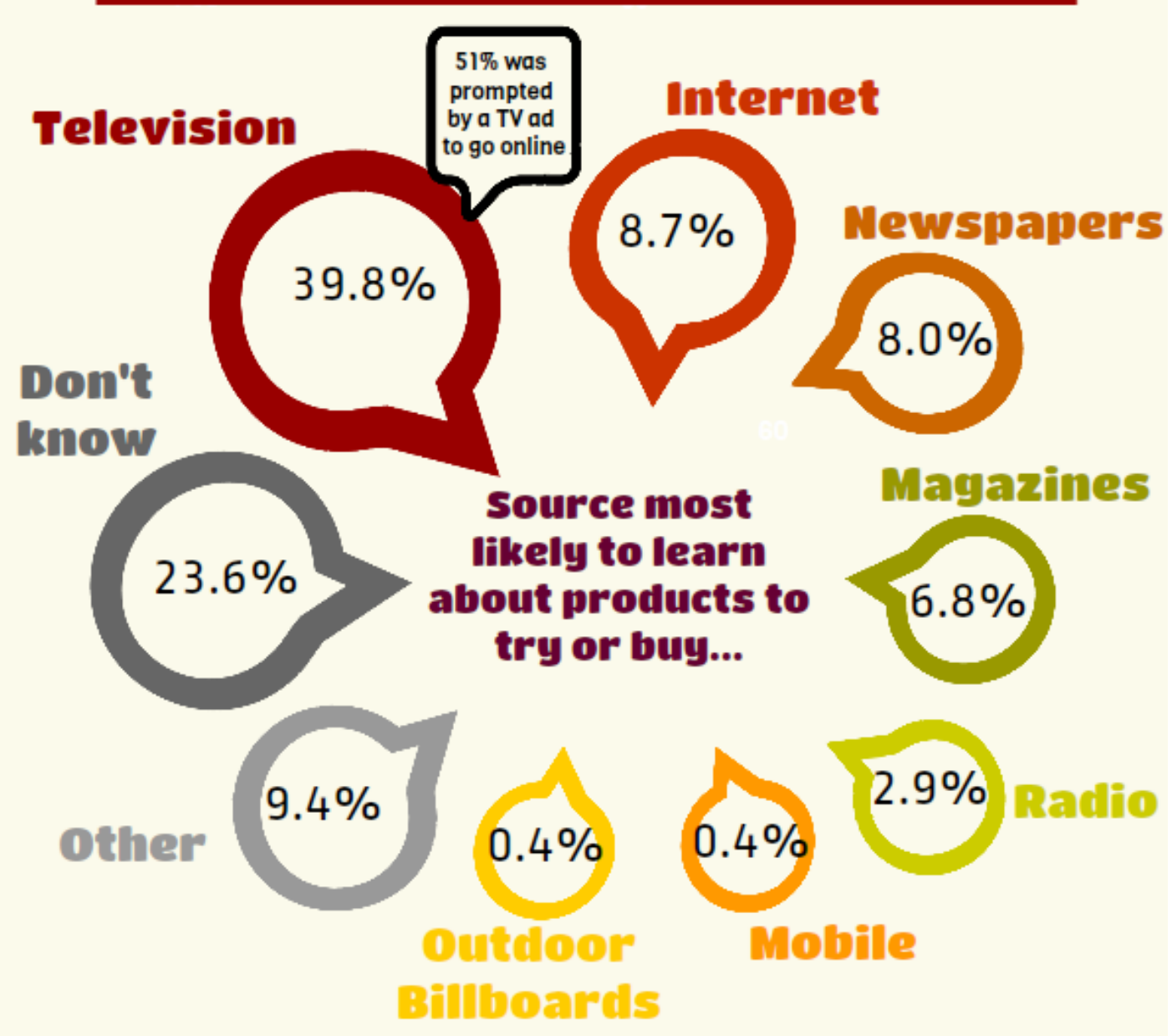

Figure 1

Percentage of Television Advertisements in Buying Behaviour of Consumers

Michaela Mora (2015)

FIGURE 2 shows the chart of the likeability of humor advertisement in television. Consumers like humor advertisements and it urge them to go for buying. 


\section{Effectiveness of Funny TV Ads}

(Funny Index correlated with standard Ace Metrix scores)

July 2012

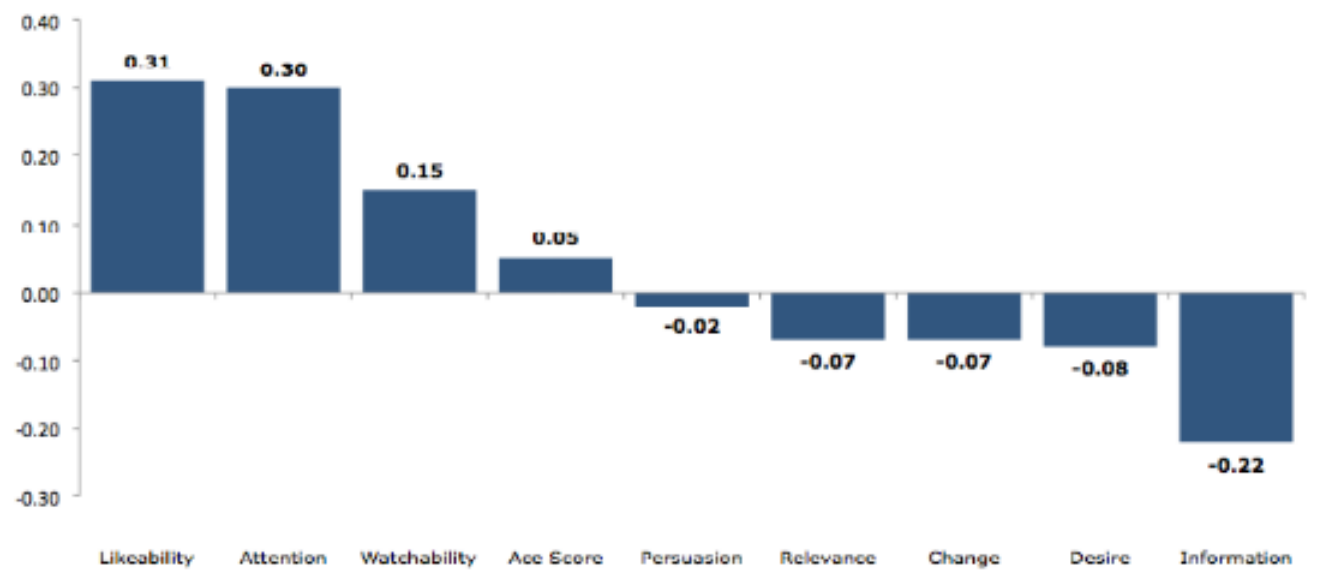

Figure 2

Chart Showing the Humor Advertisement Influences

David Erickson (2015)

FIGURE 3 depicts the conceptual framework exploring the relationship on how humor in television advertising would affect the buying behavior of consumers depending upon the demographic profiles to which they belong:

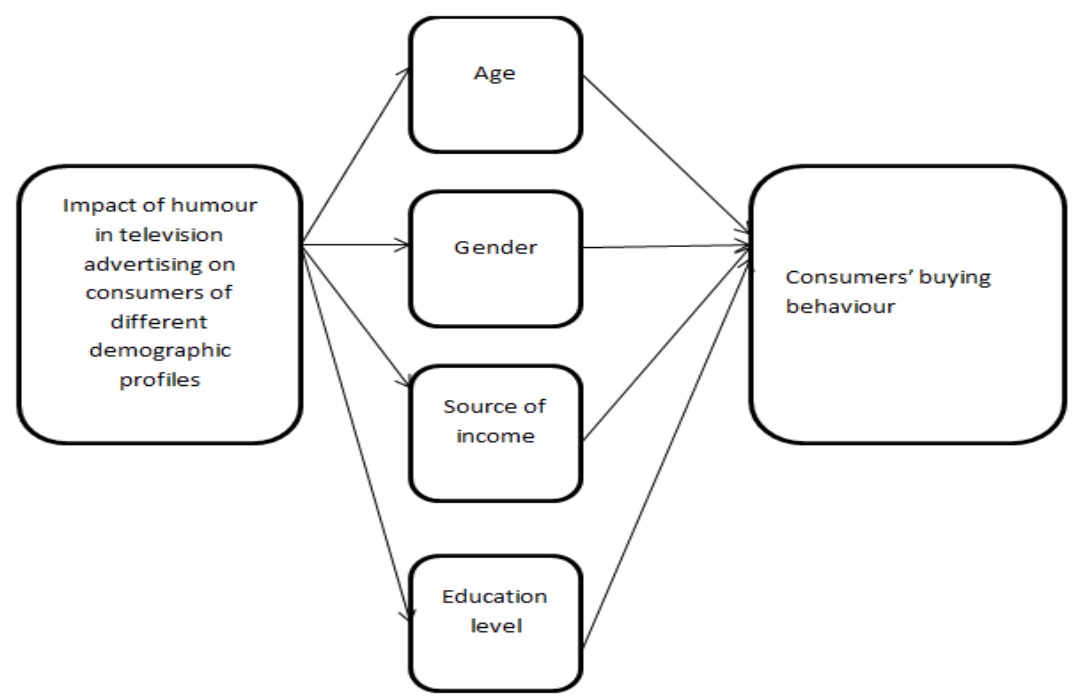

Figure 3

Framework on Impact of Humour in Television Advertising on Consumers' Buying Behavior Depending Upon Various Demographic Profiles of Consumers 
Conceptual framework was developed based on the impact of humor advertising in television advertising. This proposed review has been analyzed based on the demographics variables such as age, gender, source of income and educational level. From the findings of the study, it was found that demographics factors such as gender, age, educational level and source of income have significant effect on humor advertising in television advertising.

Based on the conceptual framework, the following propositions can be arrived at for the future researchers to test and experiment:

P1: Impact of humor in television advertising on consumers' buying behavior depending upon their age

P2: Impact of humor in television advertising on consumers' buying behavior depending upon their gender

P3: Impact of humor in television advertising on consumers' buying behavior depending upon their source of income

P4: Impact of humor in television advertising on consumers' buying behavior depending upon their educational level

\section{Future Work}

The other researchers can extend this work in futurein a quantitative manner. The propositions given in this paper can be hypothetically tested by the future researchers through collection of primary data from consumers belonging to a specific region and application of statistical tools on the collected primary data. Future work can be carried out by quantitatively testing the relationship based the demographic variable of consumers namely gender, source of income, age and level of education and the extent to which they are impacted by humorous television advertisement when buying a particular product or availing a particular service. 


\section{References}

Alden. Dana \& Wayne D. Hoyer. 1993. An examination of cognitive factors related to humorousness in television advertising. Journal of AdvertisingResearch.22(2).29-37.

Apter.Michael and MitziDesselles. 2012. Disclosure humor and distortion humor: A reversal theoryAnalysis. Humor:InternationalJournal of Humor Research. 25(4). 417-436

Arockiaraj and Marlene Morais. 2014. A Study on the Consumers' Perceptive on the Ethical Dimension of Commercial Advertisement on Television. International Journal of Business and Administration Research Review.1 (7).10-14.

Attardo.Salvatore and Lucy Pickering. 2011. Timing in the performance of jokes, Humor:InternationalJournal of Humor Research. 24(2).233-250

Baber.Hasnan and AubidHussainParrey. 2013. Humour in Advertisement-Fruitful or Wastage. Retrieved on $14^{\text {th }}$ Jan 2015 fromhttp://www.academia.edu/5718519/Humour_in_AdvertisementFruitful_or_Wastage.

Babut.Raluca2012.Romanian Consumers'attitudeTowardsTvCommercials. Retrieved on $14^{\text {th }}$ Jan 2015 from http://www.mnmk.ro/documents/2012-secondpart/4-18-2-12-FFF.pdf.

Bajpai.Ashish.Manish Kumar and KusumakarGautam. 2012. Humourous Advertisements and their Effect on PurchaseBehavior of University Students retrieved on $14^{\text {th }}$ Jan 2015 from

http://www.academia.edu/3477847/Humourous_Advertisements_and_their_Effect_on _Purchase_Behaviour_of_University_Students.

Beard. Fred 2008. Humor in the Advertising Business: Theory, Practice, and Wit, Lanham, MD: Rowman and Littlefield

Brooker.George. 1981.A Comparison of the Persuasive Effects of Mild Humor and Mild Fear Appeals.Journal of Advertising Research.10 (4).29-40.

Carlson. Kieth. 2011. The impact of humor on memory: Is the humor effect about humor?,Humor: International Journal of Humor Research.24(1).21-42.

Chan. Fong Yee. 2011. Selling through entertaining: The effect of humour in television Advertising in Hong Kong.Journal of Marketing Communications.17(5).319-336.

Chang Yu Yao and SoumavaBandyopadhyay. 2013. The Impact Of American Advertising Humor On Taiwanese Consumers. International Business \& Economics Research Journal.13(1).93-102. 
Dore. Margherita. 2011. Diana Popa and Salvatore Attardo: New Approaches to the Linguistic of Humour,International Journal of Humor Research. 24(2).251-262

Eisend. Martin. 2007. Understanding two-sided persuasion: An empirical assessment of theoretical approaches. Psychology \&Marketing.24(7).615-640.

Eisend. Martin. 2009. A meta-analysis of humor in advertising. Journal of the Academy of Marketing Science.37(2).191-203.

Eisend. Martin. 2010. A meta-analysis of gender roles in advertising. Journal of the Academy of Marketing Science.38(4).418-440.

Eisend Martin. 2011. How humor in advertising works: A meta-analytic test of alternative models. Marketing letters.22(2).115-132.

Eisend Martin and Julia Plagemannand Julia Sollwedel. 2014. Gender Roles and Humor in Advertising: The Occurrence of Stereotyping in Humorous and Nonhumorous Advertising and Its Consequences for Advertising Effectiveness. Journal of advertisingResearch.43(3).256-273.

Erickson. 2015. Effectiveness of humor in TV commercials. Retrieved on 10 Sep 2015 from http://trends.e-strategyblog.com/2012/07/17/effectiveness-of-humor-in-tvcommercials-chart/1825

Flaherty. Karen. Marc. Weinberger, and Charles. Gulas. 2004. The impact of perceived humor, product type, and humor style in radio advertising.Journal of Current Issues \& Research in Advertising.26(1).25-36.

Gurkaynak.Nilgun. Ela Burcu Ucel and Mert Gunerergin. 2011. Is laughter, as the best medicine, the remedy for crisis' pain? Use of humor in marketing communications. African Journal of Business Management.5(15). 6240-6246.

Hang. Nguyen Thai 1998.Examining the relationship between demographic variables, personal values and attitudes towards various aspects of advertising: A comparative study between Vietnamese and Malaysian consumers. available at http://repository.um.edu.my/696/1/Thesis\%20Hang.pdf (accessed 14th Jan 2014)

Hoang.AnhThuc. 2013.Impact of humor in advertising on consumer purchase decision.retrieved on $14^{\text {th }}$ Jan 2015 from https://publications.theseus.fi/bitstream/handle/10024/67417/thesis_final\%20version_ Anh\%20Hoang.pdf?sequence $=1$.

Jacoby. Larry. 1991. A process dissociation framework: Separating automatic from intentional uses of memory. Journal of Memory and Language.30(5).513-541. 
Jacoby. Larry. 1998. Invariance in automatic influences of memory: toward a user's guide for the process-dissociation procedure. Journal of Experimental Psychology: Learning, Memory, and Cognition. 24(1). 3.

Jin. ChangHyun and Jorge Villegas. 2007. The effect of the placement of the product in film: Consumers' emotional responses to humorous stimuli and prior brand evaluation.Journal of Targeting, Measurement and analysis for Marketing. 15(4).244255.

Knoll.Silke.MartinEisend, and JosefineSteinhagen. 2011. Gender roles in advertising: Measuring and comparing gender stereotyping on public and private TV channels in Germany. International Journal of Advertising: The Review of Marketing Communications.30(5).867-888.

Kotler. Philip and Gary Armstrong 2010.Principles of marketing-global edition, 13th edition.NewJersey,Pearson Prentice Hall.

Krishnan.ShankerandDipankarChakravarti. 2003. A process analysis of the effects of humorous advertising executions on brand claims memory.Journal of consumer psychology.13(3).230-245.

Lammers. Bruce. 1991. Moderating Influence of Self-Monitoring and Gender on Responses to Humorous Advertising. The Journal of Social Psychology.131 (1). 57-69

Lee. Yueh-Hua. 2014. How People Respond to Different Types of Humorous Advertising.British Journal of Management \&Economics.4(9).1419-1433.

López-De-Solís, Iris, and María-Victoria Nuño-Moral. 2014 .Uso de imágenes de archivoenpublicidad audiovisual: estudio de casos. El Profesional de la información 23(1) 26-35.

MacLeod. Colin. 1991. Half a century of research on the Stroopeffect: an integrative review. Psychological bulletin.109(2).163-203.

Marcos-Recio, Juan-Carlos, Juan-Miguel Sánchez-Vigil, and MaríaOlivera-Zaldua. 2010. Modelos de gestión documental enlasagencias de publicidad. El profesional de la información 19(2).175-183.

Madden. Thomas and Marc.Weinberger 1984.Humor in Advertising: A Practitioner View. Journal of Advertising Research.24 (4).23-29.

Majid.Adeela. 2013.Cultural influence in Advertising.Retrieved on $14^{\text {th }}$ Jan 2015 fromhttps://gupea.ub.gu.se/bitstream/2077/33925/1/gupea_2077_33925_1.pdf. 
MakWingyun and Brian.Carpenter. 2007). Humor comprehension in older adults.Journal of the International Neuropsychological Society. 13(04).606-614.

McGhee. Paul. 1986. Humor across the life span: Sources of developmental change and individual differences. Humor and aging, UK,Academic press.

Mensah-Ansu.Peter.SamuelYeboahAsuamah and Joseph Amankwah. 2013. Consumer's Attitude Towards Advertisement Elements: A Survey Of Marketing Students In Sunyani Polytechnic, Ghana, West Africa. International Journal of Innovative Research in Management.4(2).13-24

Mir.Imran Anwar and Muhammad Bashir Khan. 2012. Role of Humor-Based Advertising In A Crisis Economy. Actual Problems of Economics/Aktual'niProblemiEkonomìki.129 (3).406-414.

Mora. 2015. Media influence on purchase behavior. Retrieved on 10 Sep 2015 from http://www.relevantinsights.com/tag/consumer-facts\#sthash.AHGfsW6I.dpbs

Motwani.Dharmesh and KhushbuAgarwal. 2013. Impact of Humorous Advertisements on Customers' Behavior. International Journal of Advanced Research in Management and Social Sciences.2(10).34-41.

Olsson.Veronica, and Asa Larsson 2005. Humor in advertising. Retrieved on $14^{\text {th }}$ Jan 2015 fromhttp://epubl.1tu.se/1404-5508/2005/186/LTU-SHU-EX-05186-SE.pdf.

Perks. Lisa Glebatis .2012.The ancient roots of humor theory.Journal of HumorResearch.25(2). 119-132

Pieters.Rik.LukWarlop and Michel Wedel. 2002. Breaking through the clutter: Benefits of advertisement originality and familiarity for brand attention and memory. Management Science, 48(6).765-781.

Poku.Kofi and Eric Owusu.2014.The relationship between humorous television advertisement and viewer persuasion.Journal of Marketing and Business Management.3 (1).34-38.

PokuKofi and Mark.Ampadu. 2014. The influence of advertisement on customer loyalty in the telecommunications industry in Ghana: a case study of Kumasi metropolis. Herald Journal of marketing and business management.3(1).22-33.

Prempeh-Owusu.Vida.CosmosAntwi-Boateng and Samuel YeboahAsuamah. 2013. The Effect of Advertisement on Alcohol Consumption in Sunyani Polytechnic, Ghana, West Africa.International Journal of Innovative Research and Development.2(4).853870. 
Sankaran.Shobana. 2013.A Study on the Food Product Commercials in Television with Reference to HumourAppeal.MassCommunicationJournalism.3(158). 2.

Scolari, Carlos A. 2012. Comunicación digital. Recuerdos del futuro. El Profesional de la información 21(4) : 337-340.

Shimp. Terence. 2010. Integrated Marketing Communication in Advertising and Promotion, China South Western CENGAGE Learning. .

Siddiqui.Kamran.2011. Personality Influences Advertisement Likeness.Interdisciplinary Journal of Contemporary Research in Business.3(2).631-637.

Strick.Madelijn. Rob. Holland.Rick. vanBaaren and Ad van Knippenber. 2012. Those who laugh are defenseless: How humor breaks resistance to influence." Journal of Experimental Psychology: Applied , 18(2). 213. http://www.communicationcache.com/uploads/1/0/8/8/10887248/those_who_laugh_a re_defenseless-_how_humor_breaks_resistance_to_influence.pdf (accessed 14th Jan 2015).

Soto-Hernández, Silvano, and Catalina Naumis-Peña.2014 Análisisbibliotecológico de losnoticierostelevisivosmexicanosen la Web.ElProfesional de la información 23(1) 80-86.

Sutton-Spence.Rachel, and Donna Jo Napoli. 2011. Deaf jokes and sign language humor, Humor:InternationalJournal of Humor Research. 24(3).311-338.

Swani.Kunal. Marc. Weinberger and Charles.Gulas. 2013. The Impact of Violent Humor on Advertising Success: A Gender Perspective. Journal of Advertising,.42(4).308-319.

Turckes.Megan and Sam Burss. 2010. Gender Differences with Certain Typologies of Humour. Humor and Advertisements retrieved on $14^{\text {th }}$ Jan 2015 from https://mturckes.files.wordpress.com/2010/12/project1501.pdf

Weinberger.Marc and Harlan.Spotts. 1989. A Situational View of Information Content in TV Advertising in the US and UK. The Journal of Marketing. 53. 89-94.

Whipple. Thomas and Courtney. 1981. How Men and Women Judge Humor: Advertising Guidelines for Action Research. Current issues and research in advertising. 4(1).4356.

Yoong. David2012. The case of humor in the Malaysian House of Representatives, Humor: 25(3).263-284. 